\title{
Freshwater crab origins-Laying Gondwana to rest
}

\author{
Sebastian Klaus ${ }^{\mathrm{a}, \mathrm{b}, *}$, Darren C.J. Yeo ${ }^{\mathrm{b}}$, Shane T. Ahyong ${ }^{\mathrm{c}}$ \\ ${ }^{a}$ Department of Ecology and Evolution, Goethe-University, Siesmayerstrasse 70A, 60054 Frankfurt am Main, Germany \\ ${ }^{\mathrm{b}}$ Department of Biological Sciences, National University of Singapore, 14 Science Drive 4, Singapore 117543, Republic of Singapore \\ ${ }^{\mathrm{c}}$ Australian Museum, 6 College St., Sydney, NSW 2010, Australia
}

Received 17 September 2010; received in revised form 16 June 2011; accepted 4 July 2011

\begin{abstract}
We review the available data on the phylogeny, palaeontology and divergence time estimation of primary freshwater crabs in relation to a hypothesized Gondwanan origin of these brachyurans, as postulated by some workers in recent decades. Known phylogenetic relationships within the Old World freshwater crabs do not correspond to the successive fragmentation of the Gondwana continent. This is strong evidence against an ancestral Gondwanan distribution of Afrotropical Potamonautidae and Asian-Australian Gecarcinucidae. The fossil record of freshwater crabs (no older than the Oligocene) and heterotreme brachyurans also postdate the initial break up of Gondwana. Molecular-clock based time estimates for the most common recent ancestor of freshwater crab families differ profoundly, depending on the method of calibration used, and whether freshwater or marine brachyuran fossils are used as calibration points. As such, molecular clock estimates calibrated on freshwater crab fossils favour a post-Gondwanan evolution of freshwater crabs whereas calibration based on marine brachyuran fossils date their last common ancestor before the fragmentation of Gondwana.
\end{abstract}

(C) 2011 Elsevier GmbH. All rights reserved.

Keywords: Crustacea; Brachyura; Freshwater crabs; Biogeography; Gondwana

\section{Introduction}

The discovery of continental drift, elaborated into the theory of plate tectonics, leads to the reconstruction of past positions and connections of continental plates, and the recognition of contiguous southern and northern continents, Gondwana and Laurasia, respectively, which separated from one another as a result of the rifting of the former supercontinent Pangaea during the Triassic. Evidence of the sequential break-up of Gondwana has frequently been used to explain the distribution patterns of various plant and animal groups by

\footnotetext{
*Corresponding author at: Department of Biological Sciences, National University of Singapore, 14 Science Drive 4, Singapore 117543, Republic of Singapore.

E-mail address: dbssebas@nus.edu.sg (S. Klaus).
}

means of vicariance, including freshwater parastacid crayfish (see Crandall et al., 2000; Toon et al., 2010).

A similar explanation has also been proposed to explain the distribution of the primary freshwater crabs. The term 'primary freshwater crabs', refers to members of five wholly freshwater families (Gecarcinucidae, Potamidae, Potamonautidae, Pseudothelphusidae, and Trichodactylidae), which are independent of the sea for larval development and dispersal, and have no marine representatives (Yeo et al., 2008). A Gondwanan origin had been suggested for the primary freshwater crabs because members of most families are presently distributed on the large landmass fragments of the former Gondwana continent that broke up at the beginning of the Middle Jurassic (see Fig. 1): the Trichodactylidae and Pseudothelphusidae in South America, the Potamonautidae in Sub-Saharan Africa, Madagascar and in the Seychelles, and 


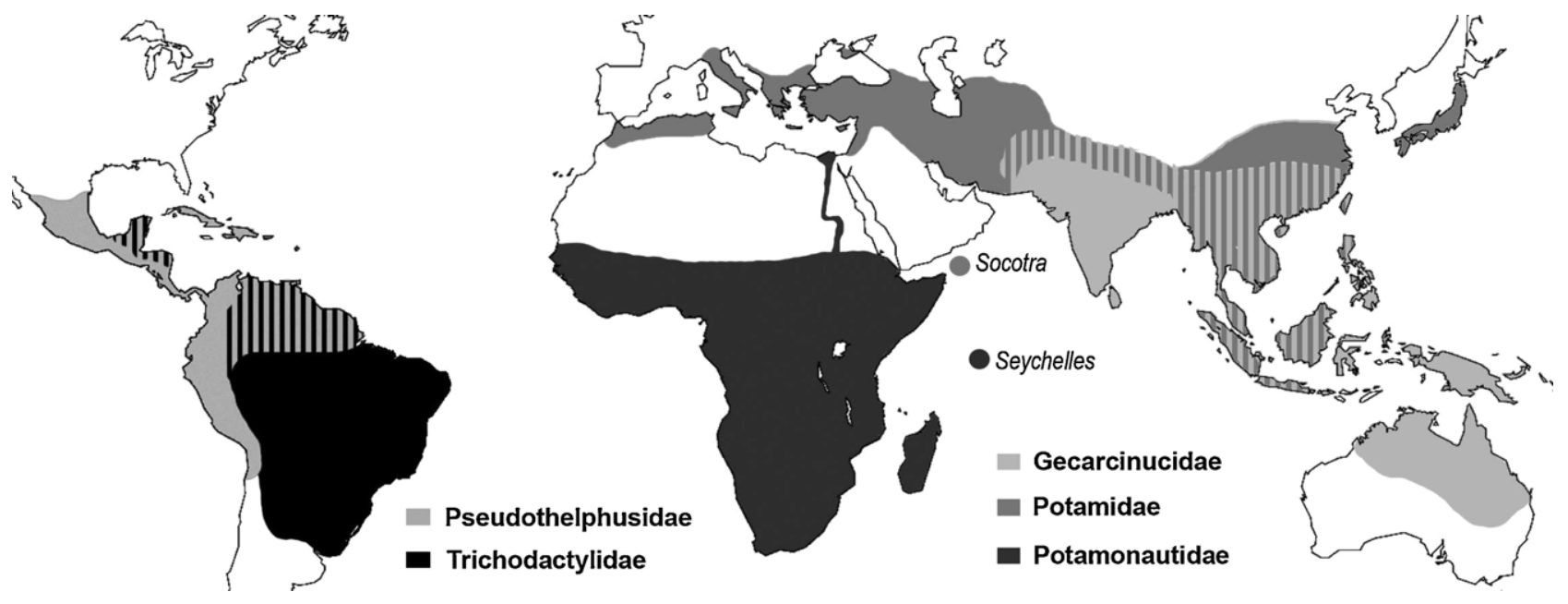

Fig. 1. Approximate distribution of the five primary freshwater crab families.

the Gecarcinucidae on the Indian subcontinent and in Australasia (including Australia and New Guinea). The Old World freshwater crab families, Gecarcinucidae, Potamidae and Potamonautidae are currently regarded as forming a monophyletic group, possibly also including the Neotropical Pseudothelphusidae (Sternberg et al., 1999; Cumberlidge and Ng, 2009; but see Klaus et al., 2009). In contrast, members of the neotropical Trichodactylidae are believed to have had a separate phylogenetic origin from other primary freshwater crab families (Sternberg et al., 1999; Cumberlidge and Ng, 2009; Schubart and Reuschel, 2009).

Initial hypotheses of a possible Gondwanan origin were tentatively expressed, mainly based on the presumed monophyly of primary freshwater crabs sharing a bilobed mandibular palp (Rodríguez, 1986; Ng and Rodríguez, 1995). This, combined with several of the major clades occurring on remnants of the Gondwanan continent, was seen to support a Gondwanan origin, in many respects paralleling that of freshwater parastacid crayfish. These major clades of freshwater crabs include the Neotropical Pseudothelphusidae, the Afrotropical Potamonautidae and part of the Asian-Australian Gecarcinucidae. A close relationship between Madagascan and Indian, as well as Neotropical and African freshwater crabs was already hypothesized by Gerstaecker and Ortmann (1901), though, predating plate tectonic theory, explained by ancestral land bridges, i.e. Sclater's (1864) early Tertiary "Lemuria" and von Ihering's (1907) Mesozoic "Archhelenis". While later studies favoured dispersal scenarios to explain the distribution of freshwater crabs, e.g. by multiple invasions into the limnic habitat (e.g. see Bott, 1970), it was Ng et al. (1995), who explicitly expressed the potential of a Gondwanan origin for freshwater crabs.

In contrast, most of the more recent phylogenetic studies on freshwater crabs explicitly rejected an ancient Gondwanan origin, favouring more recent scenarios (Sternberg et al., 1999; Sternberg and Cumberlidge, 2001; Daniels et al., 2006; Klaus et al., 2006, 2010; Cumberlidge and Ng, 2009). Unlike the parastacid crayfish, however, primary freshwater crabs as a whole cannot be regarded a priori as a uniquely or even a principally southern hemisphere faunal element. Rather the speciose family Potamidae and a fair number of the Gecarcinucidae (excluding the Indian and Australasian species), which account for more than half of all known primary freshwater crab species, occur on the continental landmass of former Laurasia (including southern Europe and western, central, and eastern Asia; see Ng et al., 2008; Yeo et al., 2008). Nevertheless, a Gondwanan origin of freshwater crabs continues to draw debate and discussion, with new fossil and molecular evidence becoming available in recent years, and lively presentations at the last two International Crustacean Congresses, in Glasgow-2005 and Qingdao-2010. Therefore, to facilitate continuing discourse, we summarize and discuss the current evidence for and against a Gondwanan origin for primary freshwater crabs as well as important questions/challenges remaining.

As different scenarios on the origins of primary freshwater crabs have recently been addressed in the review of Cumberlidge and $\mathrm{Ng}$ (2009), we focus instead on the evidence proposed for a Gondwanan origin and review how well this hypothesis fits the currently available data on mandibular palp morphology, biogeography, phylogeny, divergence time estimates and the known fossil record of primary freshwater crabs. We also consider how the possible monophyly of primary freshwater crabs and the relationship between freshwater crab families could either support a Gondwanan framework, or argue against it.

\section{Mandibular palp morphology}

A key assumption underpinning the Gondwanan hypothesis is that the bilobed terminal segment of the mandibular palp is a synapomorphy uniting the Neotropical pseudothelphusids with the Paleotropical gecarcinucids (Rodríguez, 1986; Ng and Rodríguez, 1995; Ng et al., 1995). Among 
brachyurans, the bilobed mandibular palp is unique to the primary freshwater crabs and is probably apomorphic. Indeed, the bilobed mandibular palp is a consistent and useful diagnostic character of these families (likewise the single-lobed palp in the Potamidae). However, considerable variation in this trait is present within the family Potamonautidae, which has raised serious doubts over its reliability as a suprafamilial or higher-level synapomorphy (see review in Cumberlidge and $\mathrm{Ng}$, 2009). Important questions, therefore, include whether or not the bilobed mandibular palp has arisen independently within different clades of primary freshwater crabs, which would certainly be so in the case of polyphyly. If the primary freshwater crabs are monophyletic, however, the bilobed mandibular palp could indeed represent a synapomorphy within this group. In view of the above ambiguities in the interpretation of the mandibular palp and its derivation, we presently regard this character as providing equivocal support for monophyly of primary freshwater crabs. Thus, determining whether or not freshwater crabs are monophyletic will require other lines of evidence.

\section{Monophyly of primary freshwater crabs}

Testing the monophyly of the primary freshwater crabs is complicated by several issues that are yet to be resolved. The most important is the need for unequivocal identification of the marine sister group(s) of primary freshwater crabs. This would allow a robust test of their monophyly, in particular, to determine (1) if the Old World freshwater crabs are monophyletic, (2) if so, how the three Old World families may be related, and (3) if the Neotropical Pseudothelphusidae are sister to or nested among Old World freshwater crab families as suggested by Daniels et al. (2006). A sister-group relationship between the New World Pseudothelphusidae and Old World freshwater crabs, and in particular with the African Potamonautidae, would fit a Gondwanan scenario. Conversely, if the primary freshwater crab families do not have a monophyletic origin, their geographic distributions would probably be the result of independent invasions of the limnic habitat rather than Gondwanan vicariance.

The Old World primary freshwater crabs are generally considered to be monophyletic (Sternberg et al., 1999; Cumberlidge and Ng, 2009; Klaus et al., 2006, 2009), whereas the Neotropical Trichodactylidae and Pseudothelphusidae might not be closely related at all. Based on cladistic analyses of morphological data, the Trichodactylidae were placed close to the marine Portunidae (see Rodriguez, 1992; Sternberg, 1997; Sternberg et al., 1999; Sternberg and Cumberlidge, 2001), although this is challenged by molecular evidence (Schubart and Reuschel, 2009). Curiously, Schubart and Reuschel (2009), although focused on the Portunoidea, found potamid, pseudothelphusid and trichodactylid exemplars to form a monophylum.

The unity of the Neotropical Pseudothelphusidae and the Old World primary freshwater crab families in a single clade was recently proposed (Sternberg et al., 1999; Sternberg and Cumberlidge, 2001; Cumberlidge and Ng, 2009). This hypothesis is currently based on cladistic analyses of morphological characters, but broad-based molecular studies like those of Old World taxa are still lacking.

To date, phylogenetic studies of the primary freshwater crabs have not considered the phylogeny within a brachyuran wide context. Large-scale phylogenetic analyses of the whole Brachyura, however, may be instrumental in advancing the debate through their greater potential to test for freshwater crab monophyly and identify the marine sister group or groups in the case of non-monophyly. A preliminary large-scale molecular phylogenetic analysis of the Brachyura presented at the International Crustacean Congress 2010 (see book of abstracts, Ahyong et al., 2010) supported primary freshwater crab monophyly and tentatively identified the sister group to be the remaining heterotreme clades At present, the weight of evidence from morphological and molecular studies points towards a monophyletic origin of the primary freshwater crabs (probably excluding the Trichodactylidae).

The growing support for the monophyly of freshwater crabs (or at least for a large proportion of them) together with the distribution of several clades on Gondwanan remnants is consistent with a Gondwanan origin. However, if these crabs have a Gondwanan origin, their phylogenetic relationships should also contain a commensurate geographical signal, examined below.

\section{Phylogenetic considerations}

A critical tool for evaluating the historical biogeography of freshwater crabs, in whole or in part, is their phylogeny. As far as is known, primary freshwater crabs cannot survive in seawater, although tolerance to elevated salinities under experimental conditions is known for some species (Morris and van Aard, 1998; Esser and Cumberlidge, in press). Moreover, they undergo direct development and have no planktonic larval stages. Their ability to disperse is therefore tied closely to the land masses that they occupy, even if erratic, short-distance marine dispersal, e.g. by rafting, might have occurred as proposed for the colonisation of the Seychelles (Daniels, pers. comm.) and the crossing of Wallace's Line (Klaus et al., 2010). If the primary freshwater crabs had a Gondwanan origin, their phylogenetic relationships can be expected to correlate with area relationships derived from the successive splitting of Gondwana (Fig. 2).

To test a Gondwanan vicariance model based on phylogenetic topologies, we have to deal with several challenges. First, as discussed above, the monophyly of primary freshwater crabs as a whole remains unclear (although the monophyly of each of the primary freshwater crab families is well supported), and thus the phylogenetic relationships between the constituent families remains to be robustly resolved. Current family-level molecular phylogenies have focussed 


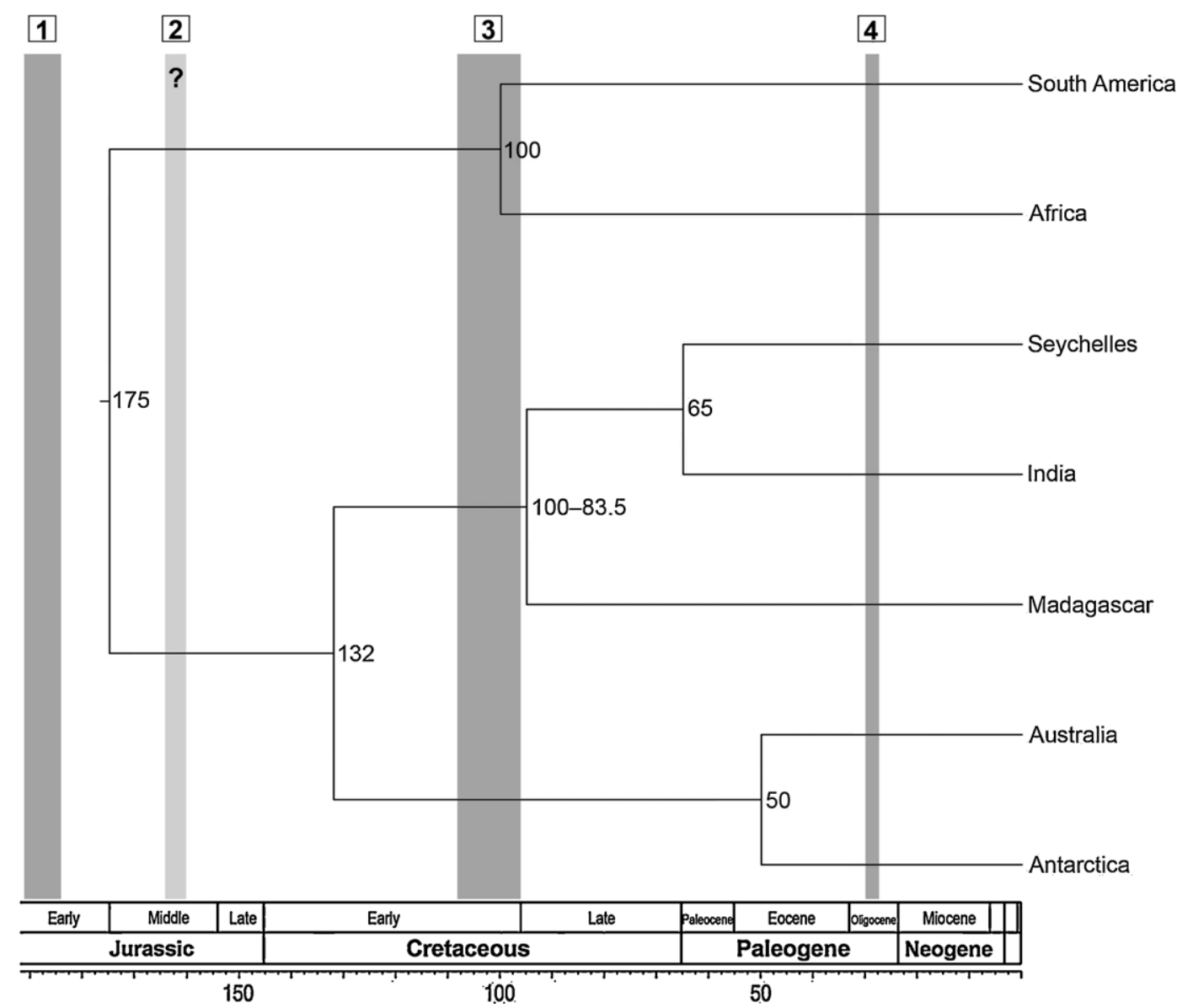

Fig. 2. Scheme of the successive breakup of the Gondwana continent. At nodes approximate divergence times are given in million years before present (see Ali and Aitchison, 2008, and references therein; geological time scale according to Ogg and Gradstein, 2008). The grey bars indicate (1) the first fossil occurrence of Brachyura; (2 and 3) first occurrence of early heterotreme crabs based on (2) a corystid of ambiguous age and (3) the confirmed dorripid fossil record; (4) the oldest known fossil freshwater crab.

on the African Potamonautidae (Daniels et al., 2006), the Eurasian Potamidae (Shih et al., 2009) and the Australasian Gecarcinucidae (Klaus et al., 2009, 2010). The topology of the potamonautid and gecarcinucid phylogenies is given in Fig. 3. The most comprehensive phylogeny of the primary freshwater crabs, Daniels et al. (2006), although focussed on Afrotropical lineages, includes representatives of all recognised families and supports overall monophyly.

Second, Neotropical pseudothelphusid and trichodactylid species are either absent or generally under-represented in current studies. Daniels et al. (2006) included a single pseudothelphusid, Guinotia dentata (Latreille, 1825) from the West Indies, which was nested among the Old World taxa. This may have prevented detection of any initial vicariant event separating Neotropical and Afrotropical freshwater crabs. Nevertheless, we can already deduce valuable information from the present phylogenetic data concerning presumed Gondwanan distribution at family level.

One basis for freshwater crabs' Gondwanan origin was initially the distribution of the superfamily Gecarcinucoidea sensu Bott (1970) (see Ng et al., 1995) uniting species from
Africa, Madagascar, the Seychelles, tropical Asia and Australia (Bott, 1965, 1970; Klaus et al., 2006). This would fit a Gondwanan pattern at a general level. However, more detailed analyses drew a different picture. Molecular phylogenies of the gecarcinucoids were not congruent with area relationships predicted by the sequential break-up of Gondwana (Daniels et al., 2006; Cumberlidge et al., 2008; Klaus et al., 2009, 2010). The monophyletic Madagascan freshwater crabs, for example, are more closely related to the African Potamonautidae than to Indian species of the family Gecarcinucidae (Daniels et al., 2006). Similarly, the freshwater crabs from the Seychelles are not the sister-group to Indian gecarcinucids as expected under a Gondwanan vicariance model, but are instead closer to African freshwater crabs (Daniels et al., 2006; Klaus et al., 2010). The Gecarcinucidae inhabit major fragments of Gondwana, i.e. they are the sole primary freshwater crab family on the Indian Subcontinent and in Australia (genus Austrothelphusa). However, it is evident from the available phylogenies, that the species east of Wallace's Line are nested within the continental Asian Gecarcinucidae (see Klaus et al., 2009, 2010). Biogeographic 

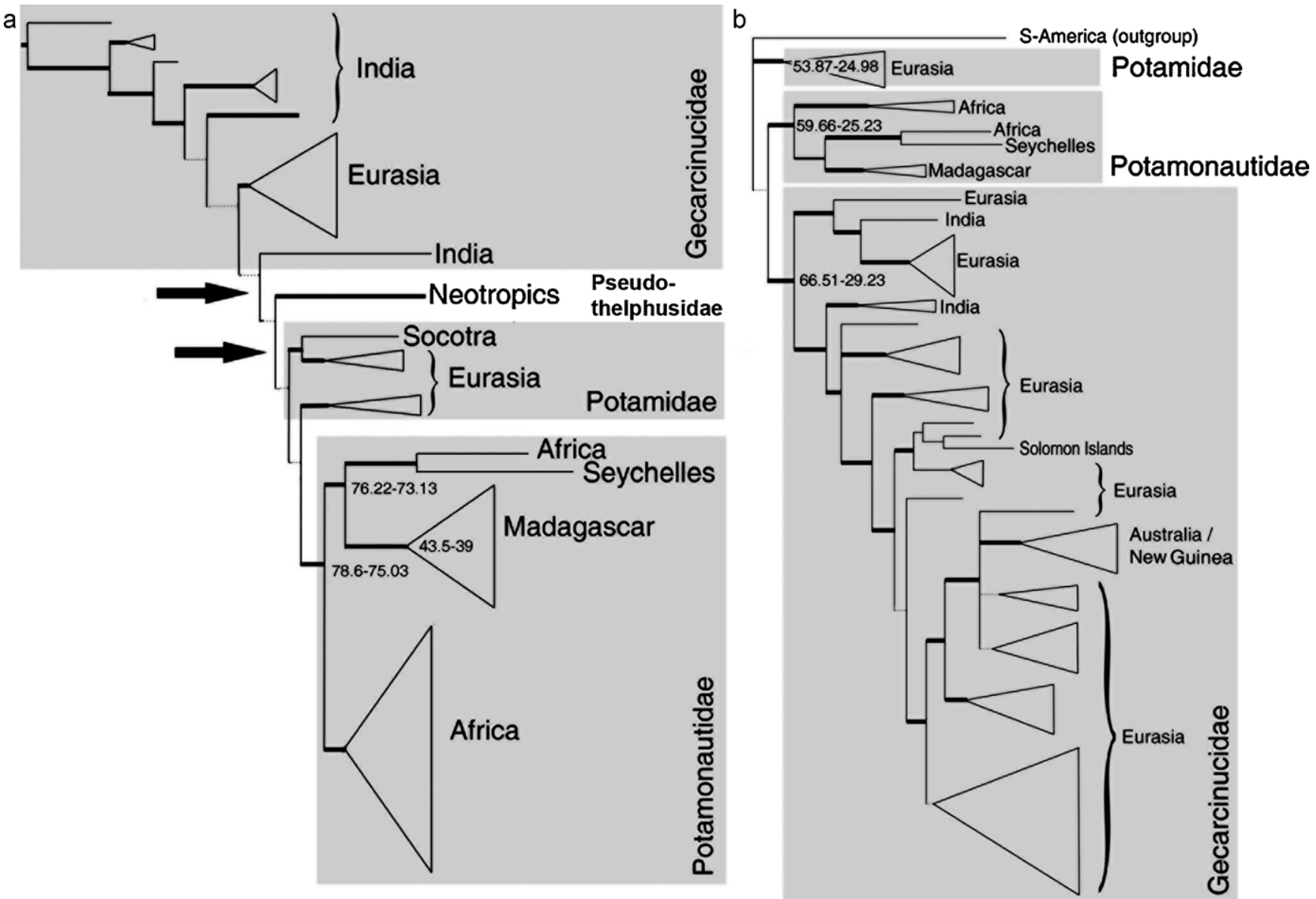

Fig. 3. Molecular phylogenies and divergence times of Old World freshwater crabs according to the studies of (A) Daniels et al. (2006), marine outgroups not shown; and (B) Klaus et al. (2009, 2010). Compare to the tectonic history of the fragmenting Gondwana continent given in Fig. 2. The arrows in (A) indicate likely positions of the root. Branches with low support are indicated by dashed lines.

inference argues for an Indian origin of the Gecarcinucidae (see Klaus et al., 2010) and several independent dispersal events into insular Southeast Asia, New Guinea and Australia (Klaus and Streit, 2011).

Thus, even if the primary freshwater crabs are monophyletic, the question would remain as to why the initial separation of Pseudothelphusidae and Old World freshwater crabs might be caused by Gondwanan vicariance while the distributions of Madagascan, Seychelles', Indian and Australasian species cannot be explained by the splitting of Eastern Gondwana. In the case of pseudothelphusid-Old World freshwater crab monophyly, it might be more parsimonious to assume either dispersal, e.g. by rafting, between the Neotropics and Afrotropics across the emerging South Atlantic Ocean or a common marine stem group (see also Cumberlidge and $\mathrm{Ng}, 2009$ ).

Like the gecarcinucids, the distribution of the Eurasian Potamidae is not easily accounted for using Gondwanan vicariance. In contrast to the gecarcinucids, however, the distributions of the Eurasian Potamidae do not include fragments of former Gondwana other than the Island of Socotra. Even on the Indian subcontinent, potamids are restricted to the northern periphery in the Himalaya and Hindu Kush. One possibility is that potamids may have dispersed secondarily into Eurasia from a Gondwanan fragment. Since potamids have not actually crossed Wallace's Line (see Yeo et al., 2008) and do not occur on the main Indian subcontinent at present, Africa would be their most probable origin under this scenario. The occurrence of potamids on the Island of Socotra on the African continental shelf, however, cannot be regarded as evidence for this possible scenario. Both morphological (Apel and Brandis, 2000) and molecular data (Shih et al., 2009) show that the freshwater crabs from Socotra are more closely related to Southeast Asian potamids and nest deeply within this clade. Moreover, the divergence time between crabs from Socotra and Southeast Asia estimated by Shih et al. (2009), $19 \mathrm{Ma}$, matches well with the initiation of continental drift between the Arabian Peninsula and Socotra (Bosworth et al., 2005).

The current phylogenetic data, as outlined here, do not favour a Gondwanan origin for each of the primary freshwater crab families. In particular, the phylogenetic relationships within the Potamonautidae and Gecarcinucidae argue strongly against it. 


\section{The fossil record}

The fossil record of freshwater crabs is scarce, not matching the considerable species diversity of extant taxa we see in extant freshwater crabs. The oldest known freshwater crab fossil, Tanzanonautes tuerkayi Feldmann et al., 2007 (Potamonautidae) from the Oligocene in East-Africa, clearly postdates the initial break-up of Gondwana by 130 million years. The earliest fossil representatives of the Potamidae, i.e. Potamon quenstedti Zittel, 1885 (Miocene of south Germany, see Klaus and Gross, 2010) and the Gecarcinucidae (claw fragments, Miocene or Pliocene of India, see Klaus and Gross, 2010, and possibly Laos, see Klaus et al., 2011) also postdate initial Gondwanan fragmentation by more than 100 million years. Of course, the fossil record provides only a minimum age for taxa, and we cannot discount its incompleteness, especially concerning freshwater sediments. $\mathrm{Ng}$ et al. (1995: 591) warned against drawing firm conclusions based on the dearth of fossils, commenting that, "the rarity and difficulty of forming (and finding) freshwater fossils is well known". Nevertheless, the fossil record of European freshwater crabs is temporally and spatially comprehensive from the Early Miocene to the present, with no earlier representatives (Klaus and Gross, 2010), whereas Eurasian Mesozoic freshwater sediments yield fossil freshwater crayfish, but no freshwater crabs (Taylor et al., 1999).

Extending our overview to the fossil record of Brachyura in general, the first unambiguous occurrence of brachyuran crabs is marked by the homolodromioid Eoprosopon from the Pliensbachian, Lower Jurassic (Schweitzer and Feldmann, 2010a,b), some 30 million years before the initial fragmentation of Gondwana. Primary freshwater crabs, however, as far as is known, are derived from heterotreme Eubrachyura. The earliest heterotremes in the fossil record are likely to be dorripids (Albian, Early Cretaceous, see Schweitzer et al., 2003). The Necrocarcinidae (first occurrence Aptian, Early Cretaceous, see Schweitzer and Feldmann, 2000) were recently removed from the heterotreme Calappoidea and assigned to the podotreme Raninoidea (see Guinot et al., 2008; Schweitzer and Feldmann, 2011), and a putative Middle Jurassic corystid (Bathonian, see Guinot et al., 2007) is most probably of Cretaceous or Cenozoic origin based on taphonomy and the age of encrusting bryozoans (Feldmann, pers. comm.). This implies, based on the fossil record, that the marine relatives of freshwater crabs may postdate initial Gondwanan fragmentation by at least $\sim 65$ million years (or $\sim 10$ million years taking into account the ambiguous Jurassic corystid, see Fig. 2). Hypothetically, this time lag could be shortened if older eubrachyuran fossils are discovered. On the other hand, the time lag between the first fossil eubrachyuran and Gondwanan fragmentation could also increase once the marine sister-group of primary freshwater crabs (or sistergroups in case they are not monophyletic) is successfully identified (because early corystids, dorippids and calappids are unlikely to be the closest relatives of freshwater crabs). Again, this can be challenged by the incompleteness of the fossil record of freshwater crabs, although this argument is less significant concerning marine sediments.

\section{Divergence time estimates}

Daniels et al. (2006) and Klaus et al. (2010) provided divergence times based on molecular clock approaches. These suggest that the Potamonautidae postdate Gondwanan fragmentation with an Upper Cretaceous (Daniels et al., 2006) or Paleocene to Oligocene age of the most recent common ancestor (Klaus et al., 2010). Although these dates differ because of different molecular clock methods and calibration points (Daniels et al., 2006 set a uniform prior for the split between African and Seychelles' species based on the age of the Seychelles, i.e. $70 \mathrm{Ma}$, possibly explaining the older divergence date), neither study supports the separation of African, Madagascan and Seychelles' potamonautids resulting from the break-up of eastern Gondwana. The most recent common ancestor of the Gecarcinucidae is dated within a large credibility interval from the Cretaceous-Paleogene transition to the Oligocene (Klaus et al., 2010). This family includes the Indian and Australasian primary freshwater crabs, which should have diverged by $132 \mathrm{Ma}$ if Gondwanan vicariance is assumed. These molecular clock studies have calibrated their substitution rates using freshwater crab fossils. Because the known freshwater crab fossil record is relatively young, its potential incompleteness may constrain the divergence estimates to more recent ages. However, the mean rate of evolution for the 16S rRNA gene of gecarcinucid freshwater crabs, resulting from fossil calibration (Klaus et al., 2010), is very close to the well-grounded rate calibrated for sesarmid crabs using the Pliocene closure of the Isthmus of Panama (Schubart et al., 1998), and is thus corroborated by independent evidence. Assuming heterogeneity of the substitution rate among different branches of a phylogenetic tree, calibration points within the freshwater crab families should lead to more reasonable divergence estimates. Furthermore, freshwater crab fossils are much more precisely dated compared to Mesozoic marine brachyuran fossils used for calibration (cf. Porter et al., 2005; Klaus et al., 2010).

Divergence time estimates for the freshwater crabs could be significantly different when considered within the wider context of an overall brachyuran phylogeny, calibrated with marine groups with a more substantial fossil record. To date few studies have taken such an approach. Porter et al. (2005) examined overall decapod relationships, but included seven Brachyura including one freshwater crab (Geothelphusa sp.), and calibrated using cancrid and majid fossils. An upper Jurassic age was estimated for the common ancestor of Geothelphusa and the thoracotreme, Pachygrapsus, postdating initial fragmentation of Gondwana. Notably, however, a Permo-Triassic age was estimated for the most recent common ancestor of the heterotreme crabs. This considerably predates the known brachyuran fossil record, although they unfortunately calibrated the most recent common ancestor 
of the Brachyura with a fossil anomuran (Eocarcinus praecursor, see Schweitzer and Feldmann, 2010a), and applied uniform priors with the fossil ages as a minimum value. The latter in particular can lead to much overestimated divergence dates (Ho, 2007). Unpublished results of a major multilocus molecular phylogeny of the Brachyura, including all primary freshwater crab groups, except the Trichodactylidae, were presented at the International Crustacean Congress 2010 (see book of abstracts, Ahyong et al., 2010), suggesting a Carboniferous origin for the Brachyura, with a Permian origin for the heterotremes, including the monophyletic Old World freshwater. Although these results are preliminary and must be interpreted with great care, they at least suggest that current divergence time estimates of the freshwater crabs may require further palaeontological and phylogenetic research within a wider brachyuran context. Thus, with respect to a Gondwanan vicariance scenario for the freshwater crabs, divergence time estimates from current molecular studies either considerably postdate or possibly predate Gondwanan fragmentation.

\section{Conclusion}

Is the theory of Gondwanan origin of primary freshwater crabs laid to rest? In light of the available data, it seems very unlikely that primary freshwater crabs are of Gondwanan origin. In contrast to examples, such as the freshwater parastacid crayfish, in which the distribution, phylogeny and fossil record together support a Gondwanan vicariance model (Toon et al., 2010), only the modern distribution (broadly considered) of primary freshwater crabs appears Gondwanan. The known fossil record of freshwater crabs is too recent, and, when closely scrutinised, the phylogenetic structure within the African/Madagascan Potamonautidae and the Asian/Australian Gecarcinucidae is incongruent with the sequential break-up of Eastern Gondwana. Thus, it is more parsimonious to conclude that dispersal shaped the present distribution patterns of primary freshwater crabs rather than fragmentation of an ancient Gondwanan range. Based on the fossil record, most divergence time estimates date the root of each of the three Old World freshwater crab families (Gecarcinucidae, Potamonautidae, and Pseudothelphusidae) dramatically later than the breaking up of Gondwana.

While the sum of current data argues against a Gondwanan origin for freshwater crabs, we nevertheless believe that every attempt should be made to further test this matter. In the process, we will inevitably develop more insights into the evolution of not only the freshwater crabs, but also their marine relatives.

\section{Acknowledgements}

We are very grateful to P.K.L. Ng, S. de Grave and two anonymous reviewers, whose suggestions substantially improved the present manuscript, and to R.M. Feldmann who kindly shared his opinion on early fossil heterotremes. We also want to express our sincere thanks to the organisers of the ICC7 in Qingdao, China, and K.H. Chu for organising the symposium on decapod phylogeny and systematics.

\section{References}

Ahyong, S.T., Tsang, L.M., Lai, J.C.Y., Chan, T.Y., Ng, P.K.L., Chu, K.H., 2010. Molecular phylogeny of the Brachyura: origin of the freshwater crabs. In: Seventh International Crustacean Congress, Program \& Abstracts, Qingdao, China, June 20-25, 2010, p. 2.

Ali, J.R., Aitchison, J.C., 2008. Gondwana to Asia: plate tectonics, paleogeography and the biological connectivity of the Indian sub-continent from the Middle Jurassic through latest Eocene (166-35 Ma). Earth-Science Reviews 88, 145-166.

Apel, M., Brandis, D., 2000. A new species of freshwater crab (Crustacea: Brachyura: Potamidae) from Socotra Island and description of Socotrapotamon nov. gen. Fauna of Arabia 18, 133-144.

Bosworth, W., Huchon, P., McClay, K., 2005. The Red Sea and Gulf of Aden Basins. Journal of African Earth Sciences 43, 334-378.

Bott, R., 1965. Die Süßwasserkrabben von Madagaskar. Bulletin du Muséum National d'Histoire Naturelle 2, 335-350.

Bott, R., 1970. Die Süßwasserkrabben von Europa, Asien und Australien und ihre Stammesgeschichte. Abhandlungen der Senckenbergischen Naturforschenden Gesellschaft 526, 1-338.

Cumberlidge, N., Sternberg, von, R., Daniels, S.R., 2008. A revision of the higher taxonomy of the Afrotropical freshwater crabs (Decapoda: Brachyura) with a discussion of their biogeography. Biological Journal of the Linnean Society 93, 399-413.

Cumberlidge, N., Ng, P.K.L., 2009. Systematics, evolution, and biogeography of freshwater crabs. In: Martin, J.W., Crandall, K.A., Felder, D.L. (Eds.), Crustacean Issues: Decapod Crustacean Phylogenetics. Francis and Taylor/CRC Press, Boca Raton, pp. 491-508.

Crandall, K.A., Harris, D.J., Fetzner, J.W., 2000. The monophyletic origin of freshwater crayfish estimated from nuclear and mitochondrial DNA sequences. Proceedings of the Royal Society of London, Series B, Biological sciences 267, 1679-1686.

Daniels, S.R., Cumberlidge, N., Pérez-Losada, M., Marijnissen, S.A.E., Crandall, K.A., 2006. Evolution of Afrotropical freshwater crab lineages obscured by morphological convergence. Molecular Phylogenetics and Evolution 40, 227-235.

Esser, L.J., Cumberlidge, N., in press. Evidence that salt water may not be a barrier to the dispersal of Asian freshwater crabs (Decapoda: Brachyura: Gecarcinucidae and Potamidae). Raffles Bulletin of Zoology, 59 (2).

Feldmann, R.M., O'Connor, P.M., Stevens, N.J., Gottfried, M.D., Roberts, E.M., Ngasala, S., Rasmusson, E.L., Kapilima, S., 2007. A new freshwater crab (Decapoda: Brachyura: Potamonautidae) from the Paleogene of Tanzania, Africa. Neues Jahrbuch für Geologie und Paläontologie, Abhandlungen 244, 71-78.

Gerstaecker, A., Ortmann, A.E., 1901. Die Klassen und Ordnungen der Arthropoden wissenschaftlich dargestellt in Wort und Bild. Fünfter Band, 1. Abtheilung: Crustacea (Zweite Hälfte: Malacostraca). In: Bronn, H.G. (Ed.), Die Klassen und Ordnungen des Thier-Reichs. C.F. Winter'sche Verlagsbuchhandlung, Leipzig, pp. 1-1319 (1290f). 
Guinot, D., De Angeli, A., Garassino, A., 2007. In: Garassino, A., Feldmann, R.M., Teruzzi, G. (Eds.), Discovery of the oldest eubrachyuran crab from the Middle jurassic (Bathonian) of Normandy (France), 3rd Symposium on Mesozoic and Cenozoic decapod crustaceans, Museo di Storia naturale di Milano, May 23-25. Memorie della Società Italiana di Scienze Naturali e del Museo Civico di Storia Naturale di Milano 35 (2), 53-55.

Guinot, D., Vega, F.J., van Bakel, B., 2008. Cenomanocarcinidae n. fam., a new Cretaceous podotreme family (Crustacea, Decapoda, Brachyura, Raninoidea), with comments on related families. Geodiversitas 30, 681-719.

Ho, S.Y.W., 2007. Calibrating molecular estimates of substitution rates and divergence times in birds. Journal of Avian Biology 38, 409-414.

von Ihering, H., 1907. Archhelenis und Archinotis. Gesammelte Beiträge zur Geschichte der neotropischen Region. W. Engelmann, Leipzig, 350 p.

Klaus, S., Schubart, C.D., Brandis, D., 2006. Phylogeny, biogeography and a new taxonomy for the Gecarcinucoidea Rathbun, 1904 (Decapoda: Brachyura). Organisms, Diversity and Evolution 6, 199-217.

Klaus, S., Brandis, D., Ng, P.K.L., Yeo, D.C.J., Schubart, C.D., 2009. Phylogeny and biogeography of Asian freshwater crabs of the family Gecarcinucidae (Brachyura: Potamoidea). In: Martin, J.W., Crandall, K.A., Felder, D.L. (Eds.), Crustacean Issues: Decapod Crustacean Phylogenetics., pp. 509-531.

Klaus, S., Gross, M., 2010. Synopsis of the fossil freshwater crabs of Europe (Brachyura: Potamoidea: Potamidae). Neues Jahrbuch für Geologie und Paläontologie, Abhandlungen 256, 39-59.

Klaus, S., Schubart, C.D., Streit, B., Pfenninger, M., 2010. When Indian crabs were not yet Asian-evidence for Eocene proximity of India and Southeast Asia from freshwater crab biogeography. BMC Evolutionary Biology 10, 287.

Klaus, S., Böhme, M., Schneider, S., Prieto, J., Phetsomphou, B., 2011. Evidence of the earliest freshwater decapod fossil from Southeast Asia (Crustacea: Decapoda: Brachyura). Raffles Bulletin of Zoology 59, 47-51.

Klaus, S., Streit, B., 2011. Pathways for freshwater fauna into Wallacea. In: Niekisch, M., Streit, B. (Eds.), Status and Future of Tropical Biodiversity. Programme \& Abstracts, Frankfurt am Main, p. 205.

Morris, S., van Aard, W.J., 1998. Salt and water relations, and nitrogen excretion in the amphibious African freshwater crab. Potamonautes warreni in water and air. Journal of Experimental Biology 201, 883-893.

Ng, P.K.L., Števčić, Z., Pretzmann, G., 1995. A revision of the family Deckeniidae, Ortmann 1897 (Crustacea, Decapoda, Brachyura, Potamoidea) from the Seychelles, Indian Ocean. Journal of Natural History 29, 581-600.

Ng, P.K.L., Rodríguez, G., 1995. Freshwater crabs as poor zoogeographical indicators: a critique of Banarescu 1990. Crustaceana 68, 636-645.

Ng, P.K.L., Guinot, D., Davie, P.J.F., 2008. Systema Brachyurorum. Part I. An annotated checklist of extant brachyuran crabs of the world. Raffles Bulletin of Zoology 17, 1-286.

Ogg, J.G., Gradstein, F.M., 2008. The Concise Geologic Time Scale. Cambridge University Press, Cambridge, 184 pp.

Porter, M.L., Pérez-Losada, M., Crandall, K.A., 2005. Model-based multi-locus estimation of decapod phylogeny and divergence times. Molecular Phylogenetics and Evolution 37, 355-369.
Rodríguez, G., 1986. Centers of radiation of freshwater crabs in the Neotropics. In: Gore, R.H. (Ed.), Crustacean Issues: Crustacean Biogeography. CRC Press, Boca Raton, pp. 51-67.

Sclater, L., 1864. The mammals of Madagascar. Quarterly Journal of Science 2, 213-219.

Schubart, C.D., Reuschel, S., 2009. A proposal for a new classification of Portunoidea and Cancroidea (Brachyura: Heterotremata) based on two independent molecular phylogenies. In: Martin, J.W., Crandall, K.A., Felder, D.L. (Eds.), Decapod Crustacean Phylogenetics. Crustacean Issues, vol. 18. CRC Press/Taylor \& Francis Group, Boca Raton/London/New York, pp. 533-549.

Schubart, C.D., Diesel, R., Hedges, S.B., 1998. Rapid evolution to terrestrial life in Jamaican crabs. Nature 393, 363-365.

Schweitzer, C.E., Feldmann, R.M., 2000. New species of calappid crabs from western North America and reconsideration of the Calappidae sensu lato. Journal of Paleontology 74, 230-246.

Schweitzer, C.E., Feldmann, R.M., Fam, J.M., Hessin, W.A., Hetrick, S.W., Nyborg, T.G., Ross, R.L.M., 2003. Cretaceous and Eocene decapod crustaceans from southern Vancouver Island, British Columbia, Canada. NRC Research Press, Ottawa, Ontario, 66 pp.

Schweitzer, C.E., Feldmann, R.M., 2010a. Is Eocarcinus Withers, 1932 a basal brachyuran? Journal of Crustacean Biology 30, 241-250.

Schweitzer, C.E., Feldmann, R.M., 2010b. The oldest Brachyura (Decapoda: Homolodromioidea, Glaessneropsoidea) known to date. Journal of Crustacean Biology 30, 251-256.

Schweitzer, C.E., Feldmann, R.M., 2011. New fossil Brachyura (Decapoda: Homoloidea, Dorippoidea, Carpilioidea) from the United Kingdom. Bulletin of the Mizunami Fossil Museum 37, $1-15$.

Shih, H.-T., Yeo, D.C.J., Ng, P.K.L., 2009. The collision of the Indian plate with Asia: molecular evidence for its impact on the phylogeny of freshwater crabs (Brachyura: Potamidae). Journal of Biogeography 36, 703-719.

von Sternberg, R., 1997. Cladistics of the freshwater crab family Trichodactylidae (Crustacea: Decapoda): appraising the reappraisal. Journal of Comparative Biology 1, 38-51.

von Sternberg, R., Cumberlidge, N., 2001. Notes on the position of the true freshwater crabs within the brachyrhynchan Eubrachyura (Crustacea: Decapoda: Brachyura). Hydrobiologia 449, 21-39.

von Sternberg, R., Cumberlidge, N., Rodriguez, G., 1999. On the marine sister groups of the freshwater crabs (Crustacea: Decapoda: Brachyura). Journal of Zoological Systematics and Evolutionary Research 37, 19-38.

Taylor, R.S., Schram, F.R., Shen, Y.-B., 1999. A new crayfish family (Decapoda: Astacida) from the Upper Jurassic of China, with a reinterpretation of other Chinese crayfish taxa. Paleontological Research 3, 121-136.

Toon, A., Pérez-Losada, M., Schweitzer, C.E., Feldmann, R.M., Carlson, M., Crandall, K.A., 2010. Gondwanan radiation of the Southern Hemisphere crayfishes (Decapoda: Parastacidae): evidence from fossils and molecules. Journal of Biogeography 37, 2275-2290.

Yeo, D.C.J., Ng, P.K.L., Cumberlidge, N., Magalhaes, C., Daniels, S.R., Campos, M.R., 2008. Global diversity of crabs (Crustacea: Decapoda: Brachyura) in freshwater. Hydrobiologia 595, 275-286. 